\title{
ENHANCING THE EFFICENCY OF ROCK PHOSPHATE IN SALINE SOIL AS AN ENVIRONMENTAL FRIENDLY ALTERNATIVE FOR P- MANUFACTURED FERTLIZERS AND ITS EFFECTON MAIZE QUALITY AND PRODUCTIVITY
}

Helmy, A. M. ${ }^{1}$; KH. A. Shaban ${ }^{2}$ and Mona G. Abd EL-Kader ${ }^{2}$

${ }^{1}$. Soil Science Dept., Fac. of Agric., Zagazig Univ., Zagazig Egypt, 44519

2. Soil, Water and Enviro. Res. Institute, ARC, Giza, Egypt

\begin{abstract}
Two field experiments were conducted to enhance the efficiency use of rock phosphate, (RP) in a saline soil at El-Qantra Sharq, Ismailia Governorate, Egypt during the two successive summer seasons of 2011 and 2012. The rock phosphate (RP) was used as an environmental friendly alternative for $\mathrm{P}$ mineral fertilizers after alleviating the adverse effects of salt stress on soil and plant by applying compost, (CO) and the phosphate dissolving bacteria, (PDB) Bacillus megaterium var. phosphaticum, whether solely or in combinations with the rock phosphate. The effects of $\mathrm{RP}$, compost and biofertilization applied solely or in combinations on maize grains yield and its quality as well as the macronutrients $N, P$ and $\mathrm{K}$ and micronutrients $\mathrm{Fe}, \mathrm{Mn}$ and $\mathrm{Zn}$ contents and uptake values were studied. $\mathrm{RP}$ was added at three rates RP0, RP1 and RP2 corresponding to 0,31 and $47 \mathrm{~kg} \mathrm{P}^{-1}$. The obtained results could be summarized as follows: the values of weight of grains plant ${ }^{-1}$, 100 -grain weight and grains yield significantly increased due to the different treatments relative to the control. The highest values of weight of grains plant ${ }^{-1}$ and grains yield $(518 \mathrm{~g}$ and $2.81 \mathrm{Mg} \mathrm{ha}^{-1}$ ), respectively were attained due to application of RP2 + compost. While, the highest one for 100-grain weight i.e. $58.9 \mathrm{~g}$ was achieved due to the treatment RP1+ compost, Uptake values of $\mathrm{N}, \mathrm{P}$ and $\mathrm{K}$ as well as $\mathrm{Fe}, \mathrm{Mn}$ and $\mathrm{Zn}$ by maize grains increased significantly as a result of addition of the treatments solely or in combination with rock phosphate. The highest uptake values of $\mathrm{N}, \mathrm{P}, \mathrm{K}$ as well as $\mathrm{Mn}$ and $\mathrm{Zn}$ i.e.168, 41.0, $141 \mathrm{~kg} \mathrm{ha}^{-1}$ as well as 547 and $401 \mathrm{~g} \mathrm{ha}^{-1}$, respectively) were obtained due to addition of RP2 + compost treatment, while the highest Feuptake value (1036 $\mathrm{g} \mathrm{ha}^{-1}$ ) resulted owing to the compost treatment. Soil available $\mathrm{N}, \mathrm{P}$ and $\mathrm{K}$ as well as DTPA extractable Fe, $\mathrm{Mn}$ and $\mathrm{Zn}$ increased while, soil $\mathrm{pH}$ and soil $\mathrm{EC}_{\mathrm{e}}$ decreased as a result of compost and bio treatments added solely or in combinations with rock phosphate. Phosphorus use efficiency, PUE, apparent phosphorus recovery, APR and phosphorus agronomic efficiency PAE decreased as rock phosphate rate increased especially when combined with compost. The treatment RP $47 \mathrm{~kg} \mathrm{P} \mathrm{ha}^{-1}+$ compost was superior to the other treatments but statistically there were no significant difference with the treatment RP $31 \mathrm{~kg} \mathrm{P} \mathrm{ha}^{-1}+$ compost for more characters under study.

Keywords: Rock phosphate, Compost, Biofertilizers, Maize, Saline soils.
\end{abstract}

\section{INTRODUCTION}

Soil or water salinity is known to cause considerable yield losses in most crops, thereby leading to reduced crop productivity (Chaum et al., 2011). The salinity-induced crop yield reduction takes place due to a number of physiological and biochemical functions in plants grown under salinity stress which have been listed in a number of comprehensive reviews on salinity effects and tolerance in plants (Jamil et al., 2011 and Krasensky and Jonak, 
Helmy, A. M. et al.

2012). Scientists have been vying for the last many decades to overcome the problem of salinity by employing a variety of strategies. Of the various strategies currently under exploitation, improvement in salinity tolerance of crops through exogenous application of different types of organic and biological fertilizers which help in inhibitory of the adverse effect of salinity (Ehteshami et al., 2007).

Environmental problems caused by irregular application of chemical fertilizers, and excessive consumption costs have all harmful effects on biological cycles and farming stability systems; these factors altogether encourage the application of bio fertilizers (Kannayan, 2002). Maize quantity and quality increased by utilization of fertilizer, (bio fertilizers, especially), in worldwide (Ali et al., 2008 and Hasaneen et al., 2009).

Phosphorus $(\mathrm{P})$ is one of the major plant growth limiting nutrients although it is abundant in soils in both inorganic and organic forms. Phosphate solubilizing micro-organisms (PSMs) are ubiquitous in soils and could play an important role in supplying $P$ to plants in a more environmentally friendly and sustainable manner. Phosphorus is usually supplied to the plant in many different forms some of which are manufactured, i.e., phosphoric acid and calcium super phosphate, while some others are common in nature such as rock phosphate, Abou El-Yazeid and Abou-Aly (2011).

The appropriate utilization of rock phosphate (RP) as $\mathrm{P}$ source can contribute to sustainable agricultural intensification, particularly in developing countries endowed with RP resources, in addition to minimizing environmental pollution in countries where RP are processed industrially. The $\mathrm{RP}$ products are an agronomically and economically sound alternative $\mathrm{P}$ input to manufactured superphosphates (Zapata and Roy, 2004 and Schneider et al., 2010). Singh and Reddy (2011) reported that inoculation with phosphate solubilizing fungus along with rock phosphate can substitute the chemical fertilizer and help in improving the crop production.

In recent years, biofertilizers have emerged as an important component of the integrated nutrient supply system and hold a great promise to improve crop yields through environmentally better nutrient supplies (Wu et al., 2005). Biofertilizers are considered the most advanced biotechnology and can increase the output, improve the quality of crop production through providing the cultivated plants with macro as well as micronutrients, required for healthy growth therefore reduce the overall cost of chemical fertilizers. These biofertilizers also increase prospects of using phosphatic rocks in crop production (Khan et al., 2009). They are also responsible for developing organic, green and non-polluting agriculture. Microorganisms that allow more efficient nutrients use or increase nutrients availability can provide sustainable solutions for present and future agricultural practices (Rai, 2006). Some bacteria such as Bacillus megaterium provide plants with growth promoting substances and play major role in phosphate solubilization. Wu et al. (2005) found that application of triple inoculants not only increased nutritional assimilation of plant, but also improved soil properties. They observed that half of the amount of biofertilizer applications had similar effects when compared with organic fertilizer or chemical fertilizer treatments. 
Soil chemical and biological characteristics improved by bio fertilizer. Moreover, due to the use of low doses of chemical fertilizers, agricultural production will be free from contaminants (EL- Habbasha et al., 2007 and Salimpour et al., 2010).

The present investigation aimed at overcoming problems of saline soil concerning $\mathrm{P}$ fixation by providing an environmental friendly alternative for $\mathrm{P}$ manufactured fertilizers. This was undertaken by studying the response of maize to rock phosphate and inoculation with $B$. megaterium var. phosphaticum with regard to growth, yield and grains quality.

\section{MATERIALS AND METHODS}

Two field experiments were conducted on a saline soil using maize (Zea mays cv Triple hybrid 310) as a test crop during the two growing summer seasons of 2011 and 2012, at the Experimental farm, El-Quntra East, Ismailia Governorate, Egypt, in order to evaluate the effect of compost and biophosphate inoculation (Bacillus megaterium var. phosphaticum) as phosphate solubilizing microorganisms added solely and/or in combinations with rock phosphate on enhancing the efficiency of rock phosphate and its impact on improving grains quality and yield components as well as $\mathrm{N}, \mathrm{P}, \mathrm{K}$, $\mathrm{Fe}, \mathrm{Mn}$ and $\mathrm{Zn}$ contents of grains maize grown on this saline soil. A representative soil sample $(0-30 \mathrm{~cm})$ was taken before planting to determine physical and chemical properties. The soil was loamy sand in texture $(82.6 \%$ sand, $5.96 \%$ silt and $11.44 \%$ clay), having EC in its saturation extract of $12.9 \mathrm{dS} \mathrm{m}^{-1}$, ESP of 20.8, SAR of 18.6 and contents of $\mathrm{CaCO}_{3}$ and organic matter of 4.82 and $3.91 \mathrm{~g} \mathrm{~kg}^{-1}$, respectively. Available nutrients were $40.0 \mathrm{mg} \mathrm{N} \mathrm{kg}^{-1}$ (mineral $\mathrm{N}$ extracted by $2 \mathrm{M} \mathrm{KCl}$ ), $3.19 \mathrm{mg} \mathrm{P} \mathrm{kg}^{-1}$ (extracted by Na-bicarbonate $0.5 \mathrm{M}$ ), and $163 \mathrm{mg} \mathrm{K} \mathrm{kg}^{-1}$ (extracted by neutral $1.0 \mathrm{M}$ $\mathrm{NH}_{4} \mathrm{OAC}$ ), $2.48 \mathrm{mg} \mathrm{Fe} \mathrm{kg}^{-1}, 1.13 \mathrm{mg} \mathrm{Mn} \mathrm{kg}^{-1}, 0.63 \mathrm{mg} \mathrm{Zn} \mathrm{kg}^{-1}$ (extracted by DTPA) according to the some methods used for analysis the initial soil i.e. Black (1965), Page (1982) and KLut (1986).

The study was laid out in a split-split design within completely randomized block design with three replicates, Rock phosphate, (RP) was assigned to the main plot at three rates $\left(0,31\right.$ and $\left.47 \mathrm{~kg} \mathrm{Pha}^{-1}\right)$ and its chemical properties are shown in Table 1.

Table 1. Chemical properties of rock phosphate

\begin{tabular}{cccccccc}
\hline Component & $\mathbf{P}$ & $\mathbf{C a O}$ & $\mathrm{Fe}_{2} \mathrm{O}_{3}$ & $\mathrm{SiO}_{2}$ & $\mathbf{M g O}$ & $\mathbf{S O 4}$ & $\mathrm{CaCO}_{3}$ \\
\hline Value (\%) & 13.1 & 42.2 & 1.46 & 4.02 & 2.05 & 1.26 & 12.1 \\
\hline
\end{tabular}

The sup plots included biofertilizer Bacillus megaterium var phosphaticium, which was supplied by Bio-fertilizers Production Unit, Soil Microbiology Dept., Soils, Water and Enviro. Res. Inst., Agric. Res. Center, Giza, Egypt and sup-sup plots had compost prepared by using 5 ton of some crop residues (straw rice, maize stover and faba bean straw), air - dried and made into $5-10$ layers, each about $50 \mathrm{~cm}$ thick. $300 \mathrm{~kg} /$ weight of farmyard manure was added to each pile to enhance microorganism activity, and then 
Helmy, A. M. et al.

it was moistened with a sufficient quantity of water. Every 21 days the heap of crop residues was turned over until it became well decomposed as described by Nasef et al. (2009). The compost analysis was done according to the standard methods described by Brunner and Wasmer (1978) and the results of analyses are shown in Table (2). Compost was added one month before maize planting at a rate of 9.5 ton ha ${ }^{-1}$ which was calculated according to its total phosphorus content.

Table 2. Chemical properties of compost.

\begin{tabular}{|c|c|c|c|c|c|c|c|c|c|c|}
\hline $\begin{array}{l}\text { Moisture } \\
\text { content }\end{array}$ & $\begin{array}{c}E C \\
d S ~ m^{-1}\end{array}$ & $\mathrm{pH}$ & C & $\begin{array}{r}\mathrm{C} / \mathrm{N} \\
\text { ratio }\end{array}$ & O.M & N \% P \% K \% & $\mathbf{F e}$ & Mn & Zn & $\mathrm{Cu}$ \\
\hline$\%$ & $1: 10$ & & & & & & \multicolumn{4}{|c|}{$\left(\mathrm{mg} \mathrm{kg}^{-1}\right)$} \\
\hline 21 & 3.98 & 7.5 & 25 & 14.2 & 33 & 1.760 .511 .88 & 241 & 130 & 92 & 40 \\
\hline
\end{tabular}

The treatments under study were as follow:

$>$ Control, zero P (Rock phosphate, RP0).

> Biofertilization, (Bio) Bacillus magaterium var. phosphaticum

$>$ Compost, $(\mathrm{CO})$

$>$ Rock phosphate1, RP1 (31 kg P ha-1)

$>\mathrm{RP} 1+\mathrm{Bio}$

$>\mathrm{RP} 1+\mathrm{CO}$.

$>$ Rock phosphate2, RP2 (47 kg P ha-1)

$>\mathrm{RP} 2+\mathrm{Bio}$

$>\mathrm{RP} 2+\mathrm{CO}$.

Maize grains (Zea mays L. Triple hybrid, 310) were soaked in the solution of bio-fertilizer Bacillus megaterium for $2 \mathrm{~h}$ before planting. The inoculated grain plots were also supplied with a suspension of Bacillus megaterium culture through drilling into so near maize plants three times after 25,50 and 75 days of planting at the rate $5 \mathrm{~L}$ of the inoculant suspension / $950 \mathrm{~L}$ water ha ${ }^{-1}$. Urea $\left(460 \mathrm{~g} \mathrm{~N} \mathrm{~kg}^{-1}\right)$ was the source of nitrogen mineral fertilizer, which was applied at the rate of $238 \mathrm{~kg} \mathrm{~N} \mathrm{ha}^{-1}$ at three equal doses after 21,35 and 50 days of maize planting. while potassium sulphate $(400 \mathrm{~g}$ $\mathrm{K} \mathrm{kg}^{-1}$ ) was applied at a rate of $198 \mathrm{~kg} \mathrm{~K} \mathrm{ha}^{-1}$ in two equal doses after 21 and 45 days from sowing. Other standard agricultural practices for growing maize were carried out as recommended by the Ministry of Agriculture. The transplants were set up into the field on $25^{\text {th }}$ and $20^{\text {th }}$ of April 2011 and 2012, respectively. The area of each plot was $20 \mathrm{~m}^{2}(4 \times 5 \mathrm{~m})$ and included 8 rows $50 \mathrm{~cm}$ apart, two plants hill ${ }^{-1}$ and $15 \mathrm{~cm}$ between hills.

\section{Grain characters and calculations}

Maize grains were collected from each plot after harvesting and subjected for determination of 100-grain weight $(\mathrm{g})$, weight of grain plant ${ }^{-1}(\mathrm{~g})$ and grain yield $\left(\mathrm{Mg} \mathrm{ha}^{-1}\right)$. Representative samples of maize grains, were air dried, oven dried at $70^{\circ} \mathrm{C}$, ground and $0.5 \mathrm{~g}$ of each sample was digested using $\mathrm{H}_{2} \mathrm{SO}_{4}$ and $\mathrm{HClO}_{4}$ mixture to determine $\mathrm{N}, \mathrm{P}, \mathrm{K}, \mathrm{Fe}, \mathrm{Mn}$, and $\mathrm{Zn}$ using the methods described by Ryan et al. (1996). Crude protein in maize grains was calculated by multiplying total $\mathrm{N}$-content by 6.25 . Grain protein yield $\left(\mathrm{kg} \mathrm{ha}^{-1}\right)=$ protein content $\left(\mathrm{g} \mathrm{kg}^{-1}\right) \times$ grains yield $\left(\mathrm{Mg} \mathrm{ha}^{-1}\right)$. Total proline content was determined using fresh leaves taken after 70 days from planting according to Bates et al. 
(1973). Apparent $P$ recovery (APR) was calculated by the equation described by Echeverria and Videla (1998), APR $=[P$ uptake (fertilized plot) $-P$ uptake (zero plot) / total $P$ fertilizer rate] $X 100$. Phosphorus use efficiency (PUE) is the $P$ applied to produce yield and is defined here as the amount of grain yield per unit of applied $P$ ( $\mathrm{kg}$ of grain yield $\mathrm{kg}^{-1}$ of $P$ applied) as described by Angas et al. (2006). Phosphorus agronomic efficiency (NPE) for P was calculated according to Craswell and Godwin (1984): [grain yield (fertilized plot) - grain yield (zero plot)] / $\mathrm{P}$ fertilizer; yield and $\mathrm{P}$ fertilizer in $\mathrm{kg} \mathrm{ha}^{-1}$.

Soil sample:

Top soil samples $(0-30 \mathrm{~cm})$ were collected from all the experimental plots at the maximum growth stage, air-dried, crushed and sieved through a $2 \mathrm{~mm}$ sieve and analyzed for soil EC, $\mathrm{pH}$, and available $\mathrm{N}, \mathrm{P}, \mathrm{K}, \mathrm{Fe}, \mathrm{Mn}$ and $\mathrm{Zn}$ contents according to the some methods used for analysing the initial soil i.e. Black (1965), Page (1982) and KLute (1986).

Statistical analysis

Data analysis was done by using COSTATC software. The ANOVA test was used to determine significantly $(p \leq 0.01$ or $p \leq 0.05)$ treatment effect and Duncan Multiple Range Test was used to determine significantly of the difference between individual means (Duncan, 1955).

\section{RESULTS AND DISCUSION}

\section{Response of Some Soil Properties and Available Nutrients Content to the Applied Treatments}

Fig. 1 shows an obviously slight response for some soil properties (i.e., $\mathrm{pH}$ and EC) and Fig. 2 for available nutrient contents to the applied treatments, particularly the treatment RP2 + compost which was superior over the other treatments. The applications of rock phosphate solely or in combination with biofertilize or compost caused a noticeable reduction in the values of soil $\mathrm{pH}$ and $\mathrm{EC}_{\mathrm{e}}$ and on the other hand, a pronounced increase in soil available contents of $\mathrm{N}, \mathrm{P}, \mathrm{K} \mathrm{Fe}, \mathrm{Mn}$ and $\mathrm{Zn}$ in soil after harvest. Compost and biofertilizer treatments enhanced also the biological conditions in soil that caused nutrient uptake by plants to increase. These results can might be attributed one or more of the following reasons:

i. Organic compost decomposition tends to accelerate in the presence of microbial media of bio-fertilizer, and in turn produces active organic and inorganic acids that led to decrease soil $\mathrm{pH}$ beside of their ability to chelate metal ions ( $\mathrm{Fe}, \mathrm{Mn}$ and $\mathrm{Zn}$ ). These chelated metal ions are held in forms available for plant and consequently they are found as strategic storehouse in organo-metalic compounds that are more suitable for uptake by plant roots. The decomposed compost acts as slow release fertilizer that can supply the plants with nutritive elements slowly but over a long time and hence it minimizes their possible loses by leaching throughout the studied relatively coarse textured soil. (Mohammed, 2004).

ii. The effective role of microbial activity to reduce soil salinity stress, could be interpreted according to many opinions outlined by Ashmaye et al. (2008) who reported that many strains produce several phytohormones 
Helmy, A. M. et al.

(i.e., indole acetic acid and cytokinins) and organic acids. Such products reduce the deleterious effect of $\mathrm{Na}$-salts, and simultaneously improve soil structure, i.e., increase aggregate stability and drainable pores and hence accelerate leaching of soluble salts and soil profile with the drained water.

iii. The released soluble $\mathrm{Ca}^{2+}$ partially substitutes exchangeable $\mathrm{Na}$ and leads to reduce ESP value and formation of small clay domains. Such clay domains are coated with the released active organic acids, and then form coarse sizes of water stable aggregates which accelerate leaching of a pronounced content of soluble salts and accordingly reduce the ECe value (Ewees and Abdel Hafeez, 2010).

Fig. 1 shows that the lowest soil $\mathrm{pH}$ and $\mathrm{EC}_{\mathrm{e}}$ values i.e. 7.96 and 7.92 $\mathrm{dSm}^{-1}$, respectively were achieved due to the treatment RP2 + compost caused decreases of 1.60 and $22.4 \%$, respectively. The mean values of available $\mathrm{N}, \mathrm{P}, \mathrm{K}, \mathrm{Fe}, \mathrm{Mn}$ and $\mathrm{Zn}$ in soil after harvest were increased and their highest values were $54.2,6.30,241,3.39,1.96$ and $0.90 \mathrm{mg} \mathrm{kg}^{-1}$, respectively owing to the treatment RP2 + compost (Fig., 2).

\section{प2011 72012 ICombined}
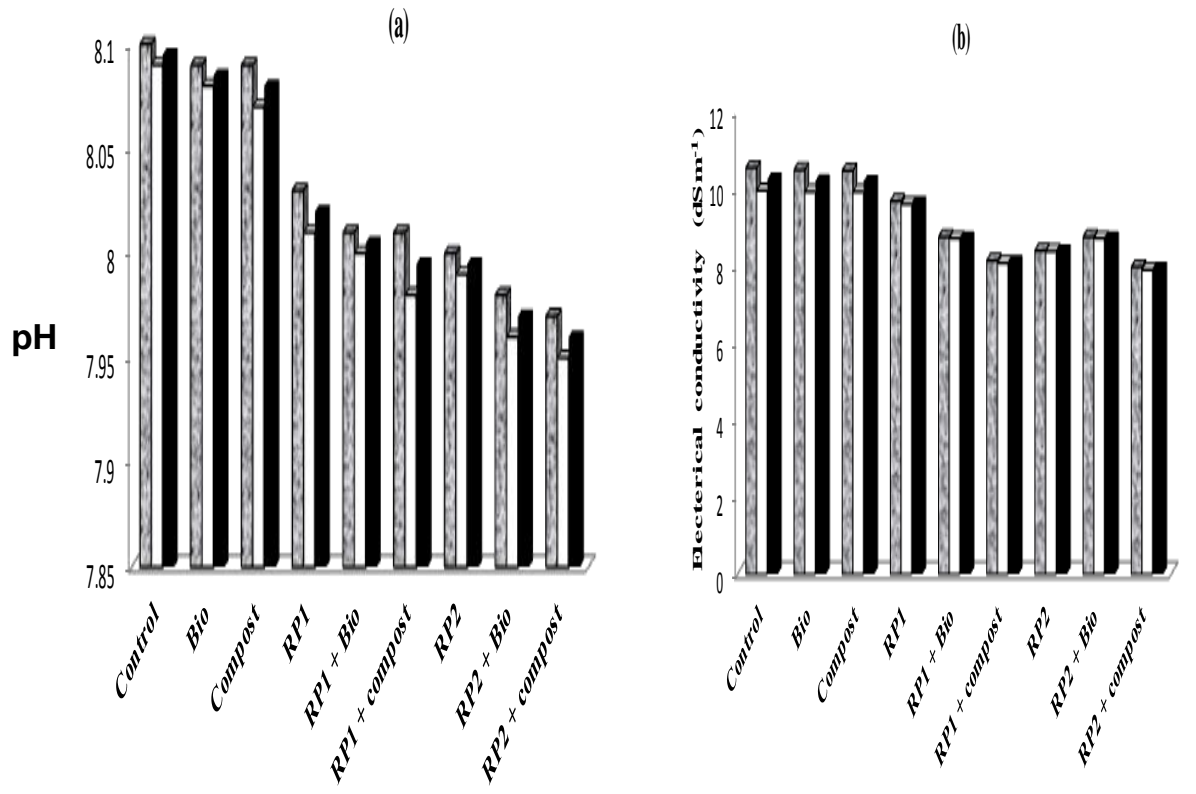

RP1: rock phosphate $\left(31 \mathrm{~kg} \mathrm{P} \mathrm{ha}^{-1}\right)$; RP2: rock phosphate $\left(47 \mathrm{~kg} \mathrm{P} \mathrm{ha}^{-1}\right)$ Fig. 1 Soil $\mathrm{pH}$ (a) and $\mathrm{EC}_{\mathrm{e}}$ (b) after harvest as affected by the investigated treatments 

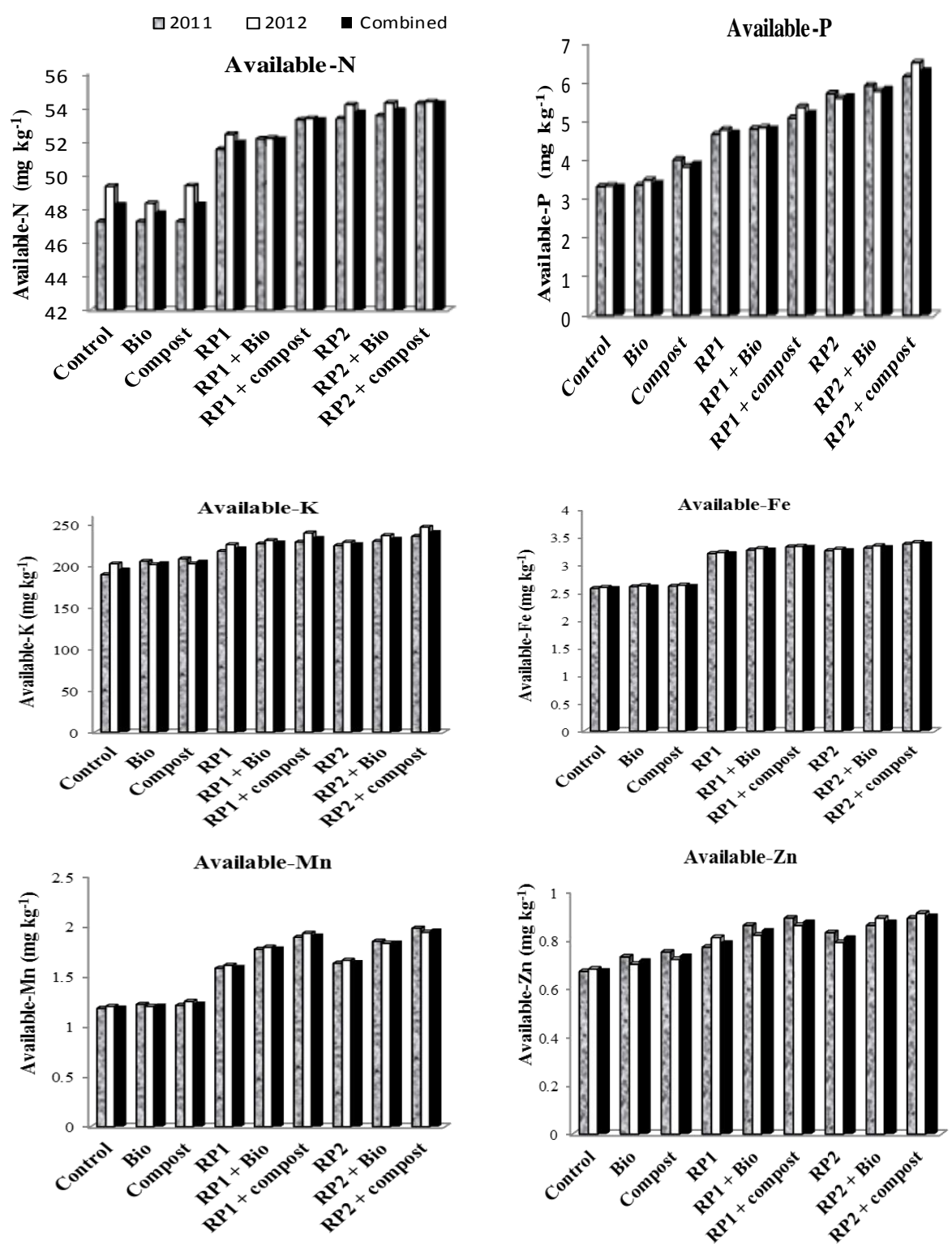

RP1: rock phosphate (31 $\left.\mathrm{kg} \mathrm{P} \mathrm{ha}^{-1}\right)$; RP2: rock phosphate (47 $\mathrm{kg} \mathrm{P} \mathrm{ha}^{-1}$ )

Fig. 2 Available N, P, K, Fe, Mn and $\mathrm{Zn}$ in soil after harvest as affected by the investigated treatments 


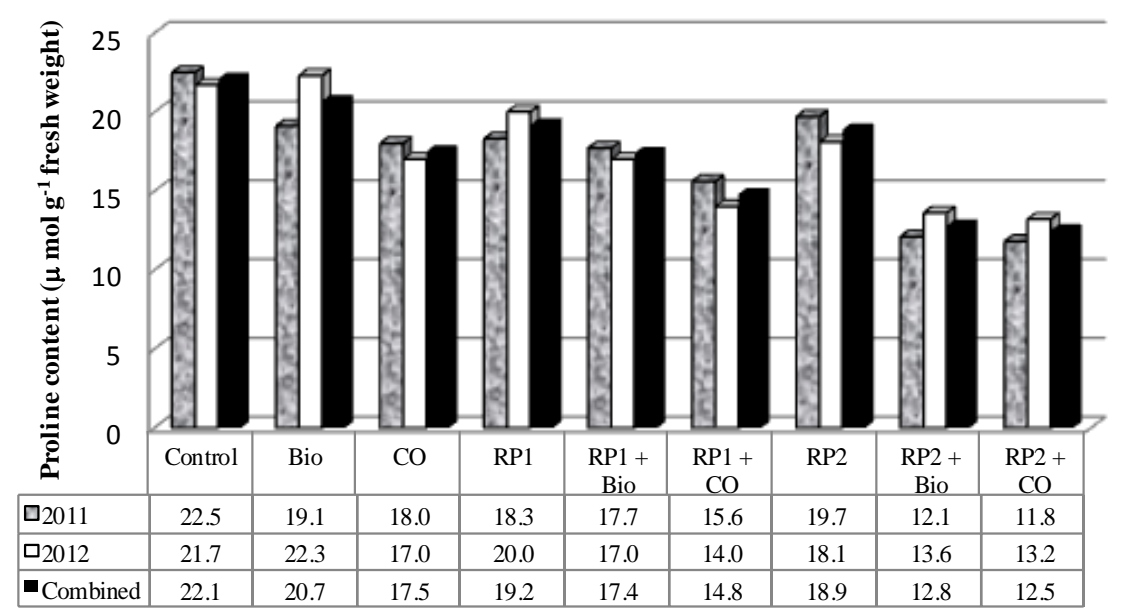

\section{CO: Compost; RP1: Rock phosphate (31 kg P ha-1); RP2: Rock phosphate (47 kg P ha-1)}

Fig 3. Proline content ( $\mu$ mol $\mathrm{g}^{-1}$ fresh weight) as affected by the investigated treatments

\section{Plant growth and grains yield}

Table 3 shows that application of rock phosphate, compost and biofertilizer solely as well as their combinations, significantly, increased the weight of maize grains plant ${ }^{-1}$ and 100 -grain weight particularly the double combined ones, as compared to the solely applied ones and control. ElGhozoli (2008) found that soybean receiving either rock phosphate or the biofertilizer of PDB or both gave higher yields than the non-fertilized treatment. This illustrates the combined stimulating effect of phosphate dissolving bacteria and rock phosphate. These results are in agreement with those obtained by Mehasen and El-Ghozoli (2003). Abd El-Hamed et al. (2013) indicated that applying P significantly increased the grain and straw yields of wheat under saline conditions as compared with the control. Also, the combined application of a mixture of superphosphate (SP) and cattle manure (CM) surpassed either SP or CM when applied alone. The yield increase due to $P$ application under saline conditions was perhaps related to the increased concentration and uptake of essential plant nutrients and the decreased concentration and uptake of toxic ions $\left(\mathrm{Na}^{+}\right.$and $\left.\mathrm{Cl}^{-}\right)$, and to the widening of the $\mathrm{Ca} / \mathrm{Na}$ and $\mathrm{K} / \mathrm{Na}$ ratios. These results are in a harmony with those obtained by Manoochehr, et al. (2011) and Mohamed, (2013).

Regarding the statistical analyses of weight of grains plant $^{-1}$, data show that there were no significant differences between the double treatments RP1 + biofertilizer, RP1 + compost, RP2 + Biofertilizer and RP2 + compost or between the solely treatments of RP1 and RP2 which had the same letters. 
As for 100-grain weight, the highest value $(58.9 \mathrm{~g})$ was obtained due to the treatment RP1 + compost which increased by $90.6 \%$ compared with the control.

With respect to grains yield, there were slightly significant differences between the treatments RP2 + compost, RP1 + compost and compost which increased grains yield by $33.2,30.87$ and $29.4 \%$, respectively followed by RP2 + biofertilizer and RP1 + biofertilizer treatments with no significant differences between them and gave increases in grain yield of about 28.0 and 27.0 , respectively. These increases illustrate the pronounced effect of compost and bio inoculation with phosphate dissolving microorganisms on improving soil characteristics, fertility and plant production. Moreover, inoculation of plants grown in salt-affected soils with salt-tolerant microorganisms increased their tolerance against salinity, thereby, increased their productivity, saved mineral fertilizer and decreased environmental pollution. (Nour El-Dein and Salama, 2006). The used treatments can be arranged according to their beneficial effect on grains yield of maize as follow: RP2+compost $>\mathrm{RP} 1+$ compost $>$ compost $>\mathrm{RP} 2+$ biofertilizer $=$ $\mathrm{RP} 1+$ biofertilizer $>\mathrm{RP} 2=\mathrm{RP} 1>$ biofertilizer $=$ Control. This may be attributed to the effect of bacteria on dissolving insoluble $P$ in rock phosphate as well as secreting promoting growth substances, which give better growth and finally good grain yield. Seed or soil inoculation with phosphobacterien and simultaneous application of rock phosphate to soil have been reported as a possible substitute for superphosphate application apparently without any reduction in the crop yield, (Singh and Reddy, 2011). These results are in line with those obtained by Aly (2003) who stated that some bacteria are capable to produce some hormones which induce the proliferation of roots and root hairs that increase nutrient absorbing surfaces as well as produce organic acids, which solubilize inorganic and organic forms of mineral elements, and consequently increase grain yields.

\section{Grains protein content and grains protein yield}

As shown in Table 4, data reveal that the protein content and protein yield of maize grains increased as affected by the treatments compared with the control. These increases were significant for protein yield and non-significant for protein content of maize grains. The insignificant increase in protein content may be attributed to the dilution effect on nitrogen throughout growth activation induced by the studied treatments. The highest value of protein (157 $\mathrm{g} \mathrm{kg}^{-1}$ ) was obtained due to the treatment RP2 + compost which resulted in $10 \%$ increase. This could be explained by the fact that the grains had highest nitrogen concentration and uptake due to this treatment . 
Helmy, A. M. et al.

Table 3. Grain yields and growth characters of maize plants as affected by the investigated treatments

\begin{tabular}{|c|c|c|c|c|}
\hline Treatment & Season & $\begin{array}{l}\text { Weight of grain } \\
\text { Plant }^{-1}(\mathrm{~g})\end{array}$ & $\begin{array}{c}\text { 100-grain weight } \\
\text { (g) }\end{array}$ & $\begin{array}{c}\text { Grains yield } \\
\left(\mathrm{Mg} \mathrm{ha}^{-1}\right)\end{array}$ \\
\hline \multirow{3}{*}{${ }^{\S}$ Control } & 2011 & 289 & 30.7 & 2.07 \\
\hline & 2012 & 291 & 31.1 & 2.14 \\
\hline & Average & $290 \mathrm{~d}$ & $30.9 \mathrm{~g}$ & $2.11 \mathrm{~d}$ \\
\hline \multirow{4}{*}{$\begin{array}{l}\text { Biofertilization, } \\
\text { (Bio) }\end{array}$} & 2011 & 375 & 38.9 & 2.12 \\
\hline & 2012 & 389 & 40.9 & 2.18 \\
\hline & Average & $382 \mathrm{c}$ & $39.9 \mathrm{f}$ & $2.15 \mathrm{~d}$ \\
\hline & 2011 & 390 & 41.0 & 2.66 \\
\hline \multirow[t]{3}{*}{ Compost, (CO) } & 2012 & 394 & 44.1 & 2.80 \\
\hline & Average & 392 c & $42.5 \mathrm{e}$ & $2.73 \mathrm{abc}$ \\
\hline & 2011 & 414 & 45.9 & 2.67 \\
\hline \multirow[t]{3}{*}{ RP1, (31 kg P ha } & 2012 & 402 & 46.0 & 2.59 \\
\hline & Average & $408 \mathrm{~b}$ & $46.0 \mathrm{~d}$ & $2.63 \mathrm{c}$ \\
\hline & 2011 & 501 & 57.9 & 2.76 \\
\hline \multirow[t]{3}{*}{ RP1+ Bio } & 2012 & 520 & 57.4 & 2.60 \\
\hline & Average & $511 a$ & $57.7 \mathrm{ab}$ & $2.68 \mathrm{bc}$ \\
\hline & 2011 & 503 & 58.7 & 2.72 \\
\hline \multirow[t]{3}{*}{$\mathrm{RP} 1+\mathrm{CO}$} & 2012 & 525 & 59.1 & 2.80 \\
\hline & Average & $514 a$ & 58.9 a & $2.76 \mathrm{ab}$ \\
\hline & 2011 & 418 & 45.9 & 2.60 \\
\hline \multirow[t]{3}{*}{ RP2, (47 kg P ha } & 2012 & 410 & 48.7 & 2.69 \\
\hline & Average & $414 \mathrm{~b}$ & $47.3 \mathrm{~d}$ & $2.65 \mathrm{c}$ \\
\hline & 2011 & 529 & 58.9 & 2.74 \\
\hline \multirow[t]{3}{*}{ RP2 +Bio } & 2012 & 505 & 54.9 & 2.66 \\
\hline & Combined & $517 a$ & $56.9 \mathrm{~b}$ & $2.70 \mathrm{bc}$ \\
\hline & 2011 & 510 & 50.2 & 2.78 \\
\hline \multirow{2}{*}{ RP2 + CO } & 2012 & 526 & 51.1 & 2.83 \\
\hline & Combined & $\begin{array}{c}518 a \\
438\end{array}$ & $\begin{array}{c}50.7 \mathrm{c} \\
47.9\end{array}$ & $\begin{array}{l}2.81 a \\
2.58\end{array}$ \\
\hline \multicolumn{2}{|l|}{ F-test (Average) } & $\star \star$ & ** & $\star *$ \\
\hline
\end{tabular}

RP: Rock phosphate

Considering the protein yield, results showed significant differences among the treatments which followed the order: RP2 + compost $>\mathrm{RP} 1+$ compost $=\mathrm{RP} 2+\mathrm{Bio}=\mathrm{RP} 1+\mathrm{Bio}=\mathrm{RP} 2>\mathrm{RP} 1=$ compost $>$ Bio $=$ control. This promoting effect could be attributed to the integrated effect of highly humified organic materials plus bio effect of phosphorus dissolving bacteria on increasing the available contents of nutrients as a storehouse for plant growth against the adverseable conditions as well as maximizing the biological yield and grain quality of maize, (Ewees and Abdel Hafeez, 2010). The highest value of protein yield was obtained due to addition of RP2 + compost which gave also the highest grain yield, nitrogen content and nitrogen uptake. 
Table 4. $\mathrm{N}$-content (\%) and uptake $\left(\mathrm{kg} \mathrm{ha}^{-1}\right)$ as well as protein content ( $\mathrm{g}$ $\left.\mathrm{kg}^{-1}\right)$ and protein yield $\left(\mathrm{kg} \mathrm{ha}^{-1}\right)$ of maize grains as affected by the investigated treatments

\begin{tabular}{|c|c|c|c|c|c|}
\hline Treatment & Season & $\begin{array}{l}\text { N-content } \\
\left(\mathrm{g} \mathrm{kg}^{-1}\right)\end{array}$ & $\begin{array}{l}\text { N-uptake } \\
\left(\text { kg ha }^{-1}\right)\end{array}$ & $\begin{array}{l}\text { Protein content } \\
\quad\left(\mathrm{g} \mathrm{kg}^{-1}\right)\end{array}$ & $\begin{array}{l}\text { Protein yield } \\
\left(\mathrm{kg} \mathrm{ha}^{-1}\right)\end{array}$ \\
\hline \multirow{3}{*}{${ }^{\S}$ Control } & 2011 & 22.2 & 110 & 139 & 46.1 \\
\hline & 2012 & 23.4 & 119 & 146 & 50.1 \\
\hline & Average & 22.8 & $115 \mathrm{c}$ & 143 & $48.1 \mathrm{c}$ \\
\hline \multirow{3}{*}{$\begin{array}{l}\text { Biofertilization } \\
\text { (Bio) }\end{array}$} & 2011 & 23.4 & 118 & 146 & 49.7 \\
\hline & 2012 & 22.5 & 117 & 141 & 49.0 \\
\hline & Average & 23.0 & $117 c$ & 144 & $49.3 \mathrm{c}$ \\
\hline \multirow{3}{*}{$\begin{array}{l}\text { Compost } \\
\text { (CO) }\end{array}$} & 2011 & 23.7 & 150 & 148 & 63.1 \\
\hline & 2012 & 22.6 & 151 & 141 & 63.3 \\
\hline & Average & 23.2 & $150 \mathrm{~b}$ & 145 & $63.2 \mathrm{~b}$ \\
\hline \multirow{4}{*}{$\begin{array}{l}\text { RP1, } \\
\left(31 \text { kg P ha }^{-1}\right)\end{array}$} & 2011 & 23.7 & 151 & 148 & 63.3 \\
\hline & 2012 & 24.3 & 150 & 152 & 63.0 \\
\hline & Average & 24.0 & $150 \mathrm{~b}$ & 150 & $63.2 \mathrm{~b}$ \\
\hline & 2011 & 24.0 & 158 & 150 & 66.3 \\
\hline \multirow[t]{3}{*}{ RP1+ Bio } & 2012 & 24.8 & 154 & 155 & 64.5 \\
\hline & Average & 24.4 & $156 a b$ & 153 & $65.4 \mathrm{ab}$ \\
\hline & 2011 & 25.6 & 166 & 160 & 69.6 \\
\hline \multirow[t]{2}{*}{$\mathrm{RP} 1+\mathrm{CO}$} & 2012 & 24.2 & 161 & 151 & 67.7 \\
\hline & Average & 24.9 & $164 a b$ & 156 & $68.7 \mathrm{ab}$ \\
\hline \multirow{4}{*}{$\begin{array}{l}\text { RP2 } \\
\left(47 \mathrm{~kg} \mathrm{P} \mathrm{ha}^{-1}\right)\end{array}$} & 2011 & 24.0 & 149 & 150 & 62.4 \\
\hline & 2012 & 25.1 & 161 & 157 & 67.6 \\
\hline & Average & 24.6 & $155 a b$ & 154 & $65.0 a b$ \\
\hline & 2011 & 25.8 & 168 & 161 & 70.5 \\
\hline \multirow[t]{3}{*}{ RP2 +Bio } & 2012 & 23.5 & 149 & 147 & 62.6 \\
\hline & Average & 24.7 & $159 a b$ & 154 & $66.6 \mathrm{ab}$ \\
\hline & 2011 & 26.3 & 174 & 164 & 73.1 \\
\hline \multirow[t]{2}{*}{$\mathrm{RP} 2+\mathrm{CO}$} & 2012 & 23.9 & 161 & 150 & 67.7 \\
\hline & Average & 25.1 & $168 a$ & 157 & $70.4 a$ \\
\hline Grand Mean & & 24.1 & 148 & 151 & 62.2 \\
\hline F-test (Average) & & & ** & NS & ** \\
\hline
\end{tabular}

\section{Macronutrients Uptake \\ Phosphorus uptake}

Phosphorus content and uptake by maize grains increased significantly as a result of the treatments and there were significant differences among the treatments as shown in Table 5. This may be due to the role of organic fertilizers which made phosphate ions being replaced by humate ion on the active sites of adsorbing surfaces. Also, the phosphate dissolving bacteria utilize organic compounds as carbon and energy source and produce organic acids, which can solubilize insoluble inorganic phosphate. These bacteria produce growth promoting substances which could influence the plant growth that roots become able to explore more soil and more zones, where phosphate ions were chemically liberated from rock phosphate fertilizer and making $\mathrm{P}$ more available to the crop, (Metwally, 2000). These findings are in agreement with those reported by Kloepper (2003), El-Sebaey (2006) and Ibrahim et al. (2008).

Effect of the treatments followed the order of, RP2 + compost $>\mathrm{RP} 1+$ compost > RP2 + Bio > RP2 > RP1 + Bio > RP1 > compost > Bio representing an increases of $111 \%, 84 \%, 74.7 \%, 69.6 \%, 57.7 \%, 40.2 \%$, $35.1 \%$ and $21.1 \%$, respectively as compared to untreated treatment (control). 
Helmy, A. M. et al.

The highest uptake value of $P 41.0 \mathrm{~kg} \mathrm{ha}^{-1}$ was observed due to addition of RP2 + compost treatment.

\section{Apparent phosphorus recovery (APR)}

The apparent phosphorus recovery (APR) parameter indicates the proportions of fertilizer $P$ recovered by the plants. As shown in Table 5, APR was greatest when $31 \mathrm{~kg} \mathrm{P}^{-1}$ was added in combination with bio inoculation by Bacillus megaterium var phosphaticu compared to the other treatments and gave $36 \%$ recovery. This means that application of a low rate of $P$ caused an enhancing effect on plant growth through causing the roots to explore a greater soil volume and absorb more $\mathrm{P}$ from the soil. The lower $\mathrm{P}$ recovery due to compost treatment is owing to the low uptake of $P$ by grains due to this treatment as compared with the other treatments. These results are in agreement with those obtained by Sweeney et al. (2000) and Fageria et al. (2011).

Table 5. P-content (\%) and uptake $\left(\mathrm{kg} \mathrm{ha}^{-1}\right)$ as well as PUE $\left(\mathrm{kg} \mathrm{kg}^{-1}\right)$, APR (\%) and PAE $\left(\mathrm{kg} \mathrm{kg}^{-1}\right)$ of maize grains as affected by the treatments

\begin{tabular}{|c|c|c|c|c|c|c|}
\hline Treatments & Season & $\begin{array}{c}\text { P-content } \\
\left(\mathrm{g} \mathrm{kg}^{-1}\right)\end{array}$ & $\begin{array}{l}\text { P-uptake } \\
\left(\mathrm{kg} \mathrm{ha}^{-1}\right)\end{array}$ & $\begin{array}{c}\text { PUE } \\
\left(\mathbf{k g ~ k g}^{-1}\right)\end{array}$ & $\begin{array}{c}\text { APR } \\
(\%)\end{array}$ & $\begin{array}{c}\text { PAE } \\
\left(\mathrm{kg} \mathrm{kg}^{-1}\right)\end{array}$ \\
\hline & 2011 & 3.21 & 15.8 & 0.00 & 0.00 & 0.00 \\
\hline \multirow{2}{*}{${ }^{\S}$ Control } & 2012 & 4.53 & 23.0 & 0.00 & 0.00 & 0.00 \\
\hline & Average & 3.87 & $19.4 \mathrm{~g}$ & 0.00 & 0.00 & 0.00 \\
\hline \multirow{3}{*}{$\begin{array}{l}\text { Biofertilization } \\
\text { (Bio) }\end{array}$} & 2011 & 5.14 & 26.0 & 0.00 & 0.00 & 0.00 \\
\hline & 2012 & 4.05 & 21.1 & 0.00 & 0.00 & 0.00 \\
\hline & Average & 4.60 & $23.5 f$ & 0.00 & 0.00 & 0.00 \\
\hline \multirow{3}{*}{$\begin{array}{l}\text { Compost } \\
\text { (CO) }\end{array}$} & 2011 & 3.33 & 21.1 & 42.6 & 10.9 & 12.1 \\
\hline & 2012 & 4.71 & 31.4 & 44.0 & 17.3 & 13.6 \\
\hline & Average & 4.02 & $26.2 \mathrm{e}$ & 43.3 & 14.1 & 12.9 \\
\hline \multirow{4}{*}{$\begin{array}{l}\text { RP1 } \\
\left(31 \mathrm{~kg} \mathrm{P} \mathrm{ha}^{-1}\right)\end{array}$} & 2011 & 4.64 & 29.5 & 68.4 & 44.2 & 19.4 \\
\hline & 2012 & 4.03 & 24.9 & 70.3 & 6.12 & 14.5 \\
\hline & Average & 4.34 & $27.2 \mathrm{e}$ & 69.4 & 25.2 & 17.0 \\
\hline & 2011 & 4.01 & 26.4 & 85.8 & 34.2 & 22.3 \\
\hline \multirow[t]{3}{*}{ RP1+ Bio } & 2012 & 5.63 & 34.8 & 90.3 & 38.1 & 14.8 \\
\hline & Average & 4.82 & $30.6 \mathrm{~d}$ & 88.1 & 36.2 & 18.6 \\
\hline & 2011 & 4.95 & 32.0 & 34.2 & 20.4 & 8.17 \\
\hline \multirow[t]{2}{*}{ RP1 + CO } & 2012 & 5.91 & 39.4 & 35.2 & 20.6 & 8.29 \\
\hline & Average & 5.43 & $35.7 \mathrm{~b}$ & 34.7 & 20.5 & 8.23 \\
\hline \multirow{4}{*}{$\begin{array}{l}\text { RP2 } \\
\left(47 \mathrm{~kg} \mathrm{P} \mathrm{ha}^{-1}\right)\end{array}$} & 2011 & 6.12 & 37.9 & 55.3 & 47.0 & 11.3 \\
\hline & 2012 & 4.35 & 27.8 & 57.2 & 10.2 & 11.7 \\
\hline & Average & 5.24 & $32.9 \mathrm{c}$ & 56.3 & 28.6 & 11.5 \\
\hline & 2011 & 4.46 & 29.1 & 58.3 & 28.3 & 14.3 \\
\hline \multirow[t]{3}{*}{ RP2 +Bio } & 2012 & 6.12 & 38.8 & 56.6 & 33.6 & 11.1 \\
\hline & Average & 5.29 & 33.9 bc & 57.5 & 31.0 & 12.7 \\
\hline & 2011 & 6.47 & 42.9 & 29.1 & 28.4 & 7.43 \\
\hline \multirow[t]{2}{*}{$\mathrm{RP2}+\mathrm{CO}$} & 2012 & 5.81 & 39.2 & 29.6 & 16.9 & 7.22 \\
\hline & Average & 6.14 & $41.0 \mathrm{a}$ & 29.4 & 22.7 & 7.33 \\
\hline Grand Mean & & 4.86 & 30.1 & & & \\
\hline F-test (Average) & & & ** & & & \\
\hline
\end{tabular}




\section{Phosphorus use efficiency (PUE)}

Data of PUE parameter, which indicates yield produced by a unit weight of fertilizer phosphorus, are shown in Table 5. The values of PUE markedly decreased as the phosphorus addition rates increased. Rock phosphate at low rate $31 \mathrm{~kg} \mathrm{P} \mathrm{ha}^{-1}$ was more efficient than $47 \mathrm{~kg} \mathrm{P} \mathrm{ha}^{-1}$. The PUE behaved similar to APR where use of $31 \mathrm{~kg} \mathrm{P} \mathrm{ha}^{-1}$ resulted in the highest PUE and decreased as $P$ level increased to $47 \mathrm{~kg} \mathrm{P} \mathrm{ha}^{-1}$ which indicates that no more $P$ fertilizer is needed to raise the efficiency of $P$ fertilization. This confirms that a reduction in $P$ fertilization can be made. The highest PUE was obtained due to addition of $31 \mathrm{~kg} \mathrm{P}^{-1}$ especially with bio inoculant of Bacillus megaterium which increased the efficiency use of phosphorus fertilization by $53.2 \%$ as compared with the high addition rate $47 \mathrm{~kg} \mathrm{P} \mathrm{ha}^{-1}+$ Bio.

\section{Phosphorus agronomic efficiency (PAE)}

Agronomic efficiency ( $\mathrm{kg}$ grain/ $\mathrm{kg} P$ applied) gave similar picture like the aforementioned two parameters (APR and PUE). Fageria et al. (2011) stated that phosphorus agronomic efficiency decreased with increasing $P$ rate. Greater agronomic efficiency at lower $\mathrm{P}$ rate indicates better $\mathrm{P}$ utilization by maize at a low $P$ rate. These types of results are common in nutritionefficiency studies in crop plants (Fageria 1992). The above three traits which behaved similarly, showed that plants absorb more $P$ when it is of low level in the soil. As the level of $P$ increased the relative absorption of $P$ went on decrease.

\section{Potassium uptake}

The results presented in Table 6 show significance differences among the treatments in increasing $\mathrm{K}$ uptake by maize grains. The average values ranged between 94.7 and $141 \mathrm{~kg} \mathrm{ha}^{-1}$ for control and RP2 + compost treatments, respectively with an increase of $49.0 \%$ compared to the control. Such positive response might reflect the different characteristics of the added compost (its chemical composition and nutritional status), hence the rate of decomposition and the differences in the subsequent release of included nutrients. However, the organic manuring addition to soil resulted in favorable soil physical conditions (such as structure), which must have affected the solubility and availability of nutrients and thus uptake of nutrients. Similar results were obtained by Mohammed (2002) and Ashmaye et al. (2008). The highest K-uptake by grains ( $\left.141 \mathrm{~kg} \mathrm{ha}{ }^{1}\right)$ was found due to the treatment RP2 + compost which was superior over the other treatments.

\section{Micronutrients Uptake}

As shown in Table 6 addition of rock phosphate, compost and bio inoculation treatments solely and in combinations significantly increased $\mathrm{Fe}$, $\mathrm{Mn}$ and $\mathrm{Zn}$ uptake by maize grains. The greatest Fe uptake (1036 $\left.\mathrm{g} \mathrm{ha}^{-1}\right)$ was observed due to the addition of compost treatment. The positive effect of organic sources on increasing Fe uptake could be attributed to one or all of the following factors: i) reducing soil pH values as a result of organic manure decomposition; ii) the high initial content of such nutrients in the applied compost; iii) the possible increases in plant growth as a result of appling such materials which also contribute to increasing Fe uptake by maize plants. 
Helmy, A. M. et al.

Table 6. $\mathrm{K}$ uptake $\left(\mathrm{kg} \mathrm{ha}^{-1}\right)$ as well as $\mathrm{Fe}, \mathrm{Mn}$ and $\mathrm{Zn}$ uptake $\left(\mathrm{g} \mathrm{ha}^{-1}\right)$ by maize grains as affected by the investigated treatments

\begin{tabular}{|c|c|c|c|c|c|}
\hline \multirow[t]{2}{*}{ Treatment } & \multirow[t]{2}{*}{ Season } & \multirow{2}{*}{$\begin{array}{l}\text { K-uptake } \\
\left(\text { kg ha }^{-1}\right)\end{array}$} & \multicolumn{3}{|c|}{$\begin{array}{l}\text { Micronutrient uptake } \\
\left(\mathrm{g} \mathrm{ha}^{-1}\right)\end{array}$} \\
\hline & & & $\mathrm{Fe}$ & Mn & $\mathrm{Zn}$ \\
\hline \multirow{3}{*}{ § Control } & 2011 & 88.8 & 399 & 304 & 166 \\
\hline & 2012 & 100 & 486 & 333 & 202 \\
\hline & Average & $94.7 \mathrm{e}$ & $442 \mathrm{e}$ & $318 e$ & $183 \mathrm{~g}$ \\
\hline \multirow{4}{*}{$\begin{array}{l}\text { Biofertilization, } \\
\text { (Bio) }\end{array}$} & 2011 & 99.3 & 534 & 326 & 175 \\
\hline & 2012 & 95.9 & 440 & 359 & 210 \\
\hline & Average & $97.6 \mathrm{e}$ & $487 \mathrm{e}$ & $343 \mathrm{e}$ & $192 \mathrm{~g}$ \\
\hline & 2011 & 126 & 570 & 441 & 261 \\
\hline \multirow{2}{*}{ Compost, (CO) } & 2012 & 125 & 1502 & 443 & 234 \\
\hline & Average & $126 \mathrm{~cd}$ & 1036 a & $442 d$ & $247 f$ \\
\hline \multirow{4}{*}{$\begin{array}{l}\text { RP1 } \\
\left(31 \mathrm{~kg} \mathrm{P} \mathrm{ha}{ }^{-1}\right)\end{array}$} & 2011 & 118 & 827 & 472 & 285 \\
\hline & 2012 & 121 & 628 & 482 & 297 \\
\hline & Average & $119 d$ & $728 d$ & $477 \mathrm{c}$ & 291 e \\
\hline & 2011 & 147 & 764 & 472 & 388 \\
\hline \multirow[t]{3}{*}{ RP1+ Bio } & 2012 & 113 & 868 & 514 & 307 \\
\hline & Average & $130 \mathrm{bc}$ & $816 \mathrm{bcd}$ & 493 bc & $347 \mathrm{c}$ \\
\hline & 2011 & 140 & 982 & 469 & 348 \\
\hline \multirow[t]{2}{*}{ RP1 + CO } & 2012 & 133 & 734 & 591 & 406 \\
\hline & Average & $137 a b$ & 858 bc & $530 a$ & $377 \mathrm{~b}$ \\
\hline \multirow{4}{*}{$\begin{array}{l}\text { RP2 } \\
\left(47 \text { kg P ha }^{-1}\right)\end{array}$} & 2011 & 127 & 799 & 519 & 301 \\
\hline & 2012 & 122 & 774 & 469 & 360 \\
\hline & Average & $125 \mathrm{~cd}$ & $786 \mathrm{~cd}$ & 494 bc & $330 \mathrm{~d}$ \\
\hline & 2011 & 124 & 784 & 485 & 354 \\
\hline \multirow[t]{3}{*}{ RP2 +Bio } & 2012 & 140 & 905 & 553 & 372 \\
\hline & Average & $132 \mathrm{abc}$ & 845 bc & $519 a b$ & $363 \mathrm{~b}$ \\
\hline & 2011 & 148 & 756 & 585 & 376 \\
\hline \multirow[t]{2}{*}{$\mathrm{RP} 2+\mathrm{CO}$} & 2012 & 134 & 1052 & 509 & 427 \\
\hline & Average & $141 a$ & $904 \mathrm{~b}$ & 547 a & 401 a \\
\hline Grand Mean & Season & 122.0 & 767 & 463 & 304 \\
\hline F-test (Average) & & ** & $\star \star$ & $\star \star$ & $\star \star$ \\
\hline
\end{tabular}

As for the statistical analysis, the increases over the control followed a descending order: compost $(134 \%)>\mathrm{RP} 2+$ compost $(105 \%) \geq \mathrm{RP} 1+$ compost $(94 \%)=\mathrm{RP} 2+$ Bio $(91 \%) \geq \mathrm{RP} 1+$ Bio $(85 \%) \geq \mathrm{RP} 2(77.8 \%)>\mathrm{RP} 1$ $(64.7 \%)>$ Bio $(10.2 \%)=$ control for Fe uptake, RP2 + compost $(72.0 \%) \geq$ RP1 + compost $(66.7 \%) \geq \operatorname{RP} 2+$ Bio $(63.2 \%) \geq \operatorname{RP} 2(55.3 \%)=\operatorname{RP} 1+$ Bio $(55.0 \%) \geq \operatorname{RP} 1(50 \%)>$ compost $(39 \%)>$ Bio $(7.86 \%)=$ control for Mn uptake and RP2 + compost $(119 \%)>\mathrm{RP} 1+$ compost $(106 \%)=\mathrm{RP} 2+$ Bio $(98.4 \%)>$ RP1 + Bio $(89.6 \%)>\operatorname{RP} 2(80.3 \%)>\operatorname{RP} 1(59 \%)>$ compost $(35 \%)>$ Bio $(4.92 \%)=$ control for $\mathrm{Zn}$ uptake. The highest $\mathrm{Mn}$ and $\mathrm{Zn}$ uptake values (547 and $401 \mathrm{~g} \mathrm{ha}^{-1}$, respectively) were recorded due to the treatment RP2+compost. Ashmaye et al. (2008) pointed out that application of organic farm manure and biofertilization caused significant increases in the concentrations of $\mathrm{Fe}, \mathrm{Mn}$ and $\mathrm{Zn}$ in maize grains grown on saline soil compared to the control. These results are in a harmony with those obtained by Salem et al. (2008) who found that, the addition of rock phosphate in presence of FYM + PSB organisms significantly increased Fe, Mn and $\mathrm{Zn}$ uptake by maize grains. These increases may be attributed to the role of organic sources on improving these micronutrients availability which were likely attributed to several reasons: 1) Releasing these nutrients through 
microbial decomposition of organic matter ; 2) Enhancing the chelation of metal ions by fulvic acid, organic legands and / or other organic function groups which may promote the mobility of metal from solid to liquid phase in the soil environment; 3) Lowering the redox statues of iron and manganese, leading to reduction of higher $\mathrm{Fe}^{3+} \& \mathrm{Mn}^{4+}$ to $\mathrm{Fe}^{2+}$ and $\mathrm{Mn}^{2+}$ and / or transformation of insoluble chelated forms into more soluble ions.

\section{CONCLUSION}

From the above mentioned results and discussion it can be concluded that, inoculation of maize grains with bio-fertilizer (Bacillus megaterium var. phosphaticum) and addition of compost as an organic amendment enhanced the soil characteristics and alleviate the adverse effects of salt stress on soil and plant and hence increased the efficiency use of rock phosphate and increased maize productivity and grains quality. Also, rock phosphate can be considered as an environmental friendly alternative for $\mathrm{P}$ mineral fertilizers sources. This approach assists farmers to increase their income through reducing the potential hazardous contamination of surface and ground water which occurs when chemical fertilizer $P$ is used. Utilization of phosphorus fertilizer decreased to $50 \%$ by integrating biological and organic phosphorus fertilizers with natural phosphorus fertilizer without yield loss. Also, environmental pollution is reduced by decreasing consumption of chemical fertilizers. Overall utilization of biological and organic phosphate fertilizers with rock phosphate fertilizer in addition to increased maize yield under saline conditions could be a strategy to achieve sustainable agriculture.

\section{REFERENCES}

Abd El-Hamed, E.M.W., Metwally, S.M., Matar, M.K. and Youssef, N.N. (2013) Effect of phosphorus in alleviation adverse impacts of salinity on wheat grown on different soils. Communications in Soil Sci. and Plant Analysis 44(13): 1921 - 1936.

Abou El-Yazeid, A. and Abou-Aly, H.E. (2011) Enhancing growth, productivity and quality of tomato plants using phosphate solubilizing microogranisms. Australian J. Basic and Apllied Sci., 5(7): 371 - 379.

Ali, S., Riaz, A.K., Ghazal, M., Arif, M., Fida, M., Saiqa, B. (2008) Assessment of different crop nutrient management practices for yield improvement. Austr. J. Crop Sci. 2(3): 150-157

Aly, M.M.M. (2003) Biological studies on some associative nitrogen fixing bacteria. MSc. Thesis, Fac. Agric., Cairo Univ., Giza, Egypt.

Angas, P., Lampurlanes, J. and Martinez, C.C. (2006) Tillage and N fertilization effects on $\mathrm{N}$ dynamics and barley yield under semiarid Mediterranean conditions. Soil and Tillage Research 87: $59-71$

Ashmaye, S.H., Shaban, Kh.A. and Abd El-Hader, M.G. (2008) Effect of mineral nitrogen, sulphur, organic and bio-fertilizers on maize productivity in saline soil of Sahl El-Tina. Minufiya J. Agric. Res., 33(1): $195-209$. 
Helmy, A. M. et al.

Bates, L.S., Waldren, R.P. and Teare, I. D. (1973) Rapid determination of proline for water stress studies. Plant and Soil, $39: 305-307$.

Black, C. A. (1965)" Methods of Soil Analysis", I \& II. Amer. Soc. Agron. Inc., Publisher, Madison, Wisconsin, USA.

Brunner, P.H. and Wasmer, H.R. (1978) "Methods of analysis of sewage sludge solid wastes and compost". W.H.O. International Reference Center for Wastes Disposal (H-8600), Dulendr of Switzerland.

Chaum S., Pokasombat, Y. and Kirdmanee C. (2011) Remediation of saltaffected soil by gypsum and farmyard manure - Importance for the production of Jasmine rice. Aust J Crop Sci 5: 458-465

Craswell, E.T. and Godwin D.C. (1984) The efficiencies of nitrogen fertilizer applied to cereals in different climates. Adv. Plant Nutr. 1: 1-55

Duncan, D.B. (1955) "Multiple Ranges and Multiple F". Test. Biometrics. II: 1- 42.

Echeverria, H. E. and Videla, C. C. (1998) Eficiencia fisiologicay de utilizacion de nitrogeno en trigo en la region pampeana Argentina. Ciencia del suelo 16: $83-87$.

Ehteshami, S.M.R., Aghaalikhani, M., Khavazi, K. and Chaichi, M.R. (2007) Effect of phosphate solubilizing microorganisms on quantitative and qualitative characteristics of maize (Zea mays L.) under water deficit stress. Pakistan J. Biological Sci. 10(20):3585-3591

El-Ghozoli, M.A. (2008) Response of soybean plants to rock phosphate application combined with phosphate dissolving bacteria under salinity condition. Zagazig J. Agric. Res., 35(4): 851 - 865.

El-Habbasha, S.F., Hozayn, M. and Khalafallah, M.A. (2007) Integration effect between phosphorus levels and bio-fertilizers on quality and quantity yield of faba bean (vicia faba I.) in newly cultivated sandy soils. Research Journal of Agriculture and Biological Sciences 3(6): 966-971.

El-Sebaey, M.M. (2006) Effect of inorganic, organic and bio-fertilizer on wheat plant grown in new cultivated land. Zagazig J. Agric. Res., 33(5): $863-876$.

Ewees, M.S.A. and Abdel Hafeez, A.A.A. (2010) Response of Maize grain to a partial substitution of $\mathrm{N}$-mineral by applying organic manure, bioinoculation and elemental sulphur as an alternative strategy to avoid the possible chemical pollution.

Fageria, N.K. (1992) Maximizing crop yields. New York: Marcel Dekker.

Fageria, N.K., Moreira, A. and Castro, C. (2011) Response of soybean to phosphorus fertilization in Brazilian oxisol. Communications in soil and Plant Analysis 42 (22): $2716-2723$.

Hasaneen, M.N.A., Younis M.E., Tourky S.M.N. (2009) Plant growth, metabolism and adaptation in relation to stress conditions XXIII. Salinity-biofertility interactive effects on growth, carbohydrates and photosynthetic efficiency of lactuca sativa. Plant Omics, 2 (2): 60-69

Ibrahim, A.M., Mostafa, M.M., El-Garhi, A.I. and Youssef, N.N. (2008) Macronutrients uptake by maize plant and their availability in the soil as affected by organic fertilization under different sources and levels of nitrogen. Zagazig J. Agric. Res., 35(5): 1127 - 1142.

Jamil A., Riaz, S., Ashraf, M. and Foolad, M.R. (2011) Gene expression profiling of plants under salt stress. Crit Rev Plant Sci 30: 435-458 
Kannayan, S. (2002) Biofertilizers for sustainable crop production, Biotechnology of Biofertilizers. Narosa Publishing House, New Delhi, India 9-49.

Khan, A.A., Jilani, G., Akhtar, M.S., Naqvi, S.M. and Rasheed, M. (2009) Phosphorus solubilizing bacteria: mechanisms and their role in crop production. J. Agric. Biol. Sci., 1(1): 48-58.

Kloepper, J.W. (2003) A review of mechanisms for plant growth promotion by PGPR $6^{\text {th }}$ international PGPR workshop. 5-10 October, Calcutta, India.

Klute, A. (1986) "Methods of Analysis". Part 1, Soil Physical Properties. ASA and SSSA, Madison, WI.

Krasensky J. and Jonak, C. (2012) Drought, salt, and temperature stressinduced metabolic rearrangements and regulatory networks. J Exp Bot 63: 1593-1608

Manoochehr, F. Mansour, A. Ali, F. and Shahram S. (2011) Phosphorus levels effects on quantitive and qualitative characteristics of corn in presence and absence of a bio-fertilizer. International Conference on Agric. and Animal Sci. (22): 129 - 132.

Mehasen, S.A.S. and El-Ghozoli, M.A. (2003) Response of soybean plants to foliar application with iron and molybdenum and soil fertilization with rock phosphate and phosphate dissolving bacteria. Minufiya J. Agric. Res., 28(1): $87-102$.

Metwally, S.G. (2000) Fertilizer use efficiency of wheat as affected by microbial inoculation and soil conditions. Ph.D. Thesis Soils Dept., Fac. Agric., Mansoura Univ.

Mohamed, B.T. (2013) Effect of different sources of phosphorus on faba bean production and grain quality. Egyp. J. Appl. Sci., 28(2): 32- 43.

Mohammed, S.S. (2002) Integrated nitrogen management to wheat through mineral and biofertilization along with organic municipal - wastes in some newly reclaimed soils of Egypt 2-Uptake and availability of nutrients. Zagazig J.Agric. Res., 29 (2): 547 - 567

Mohammed, S.S. (2004) Assessment of the relative effectiveness for some organic materials conjucted with mineral nitrogen on soil fertility status, yield and quality of wheat grown on a newly cultivated soil. Egypt $\mathrm{J}$. Appl. Sci. 19(3): $298-310$.

Nasef, M. A., Shaban, KH. A. and Abd El-Hamid, A.F. (2009) Effect of compost, compost tea and bio-fertilizer application on some chemical soil properties and rice productivity under saline soil condition. J. Agric. Mansoura Univ. 34 (4): 2609- 2623.

Nour El-Dein, M. and Salama, S.A. (2006) Significance of biofertilization for improving yield, chemical and technological properties of wheat plants grown in saline soil. Zagazig j. Agric. Res., 33(3): $501-515$.

Page, A. L. (1982) "Methods of Soil Analysis"II: Chemical and Microbiological Properties, $2^{\text {nd }}$ ed. Soil Sci. Am. Inc., Madison, USA.

Rai, M.K. (2006) "Handbook of microbial biofertilizers". Food Products Press, an imprint of The Haworth Press, Inc, Binghamton, New York. 
Helmy, A. M. et al.

Ryan, J., Garabet, S., Harmsen, K. and Rashid, A. (1996) "A soil and plant analysis". Manual Adapted for the West Asia and North Africa Region. ICARDA, Aleppo, Syria. 140p.

Salem, H.M., Abdel Salam, M.A. and Abd Elwarth M. (2008) Biofertilization of maize on sandy and clayey soils using organic and mineral $P$ fertilizers. Plant Nutrition Management under Stress Conditions. $17^{\text {th }}$ International Symposium of the International Scientific Centre of Fertilizers (CIEC), Nov. $24-27$, Cairo, Egypt.

Salimpour, S., Khavazi K, Nadian, H., Besharati, H. and Miransari, M. (2010) Enhancing phosphorous availability to canola (Brassica napus L.) using $P$ solubilizing and sulfur oxidizing bacteria. Australian Journal of Crop Science 4(5): 330-33

Schneider, K.D., Van Straaten, P., Orduña R., Glasauer, S., Trevors, J., Fallow, D. and Smith, P.S. (2010) Comparing phosphorus mobilization strategies using Aspergillus niger for the mineral dissolution of three phosphate rocks. Journal of Applied Microbiology, 108(1): 366-374.

Singh, H. and Reddy, M.S. (2011) Effect of inoculation with phosphate solubilizing fungus on growth and nutrient uptake of wheat and maize plants fertilized with rock phosphate in alkaline soils. European J. of Soil Biology, 47: 30-34.

Sweeney, D.W., Granade, G.V., Eversmeyer, M.G., and Whitney, D.A. (2000) Phosphorus, potassium, chloride and fungicide effects on wheat yield and leaf rust severity. J. Plant Nutrition, 23: $1267-1281$.

Wu, S.C., Cao, Z.H., Li, Z.G., Cheung, K.C. and Wong, M.H. (2005) Effects of biofertilizer containing $\mathrm{N}_{2}$-fixer, $\mathrm{P}$ and $\mathrm{K}$ solubilizers and $\mathrm{AM}$ fungi on maize growth: a greenhouse trial. Geoderma, 125(1/2): 155-166.

Zapata, F. and Roy, R.N. (2004) Use of phosphate rocks for sustainable agriculture. FAO fertilizer and Plant Nutrition Bulletin 13, Rome, Italy. 
زيادة كفاعة صخر الفوسفات في الأرض الملحية كبديل بيئي آمن للمصـادر المعدنية

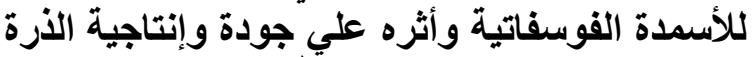

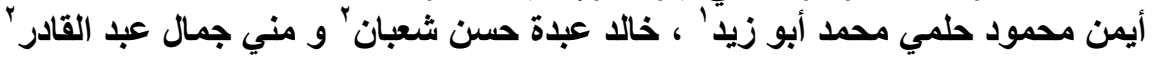

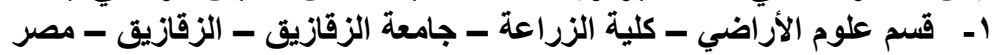

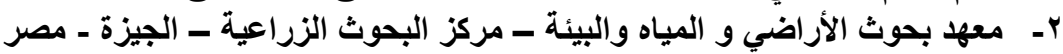

أجريت تجربتان حقليتان في مزر عة خاصة بمنطقة القطرة شرق ـ محافظة الأسماعيلية - مصر

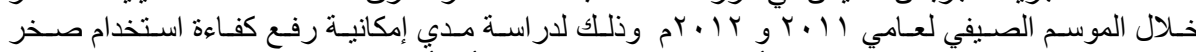

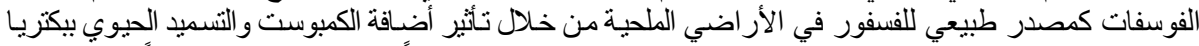

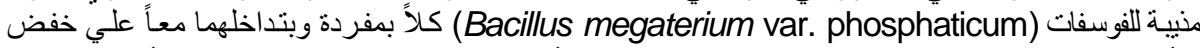

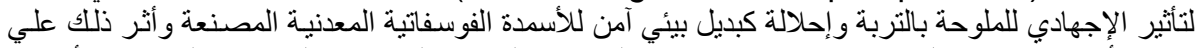

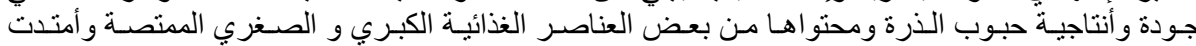

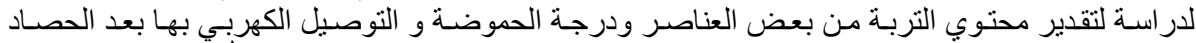

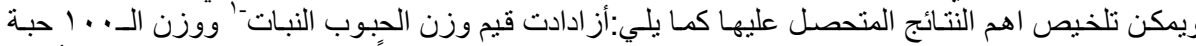

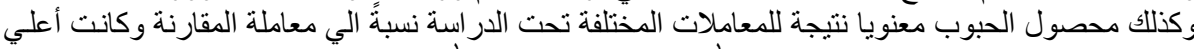

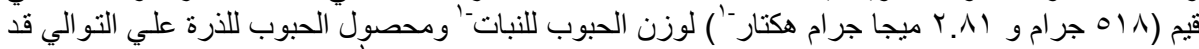

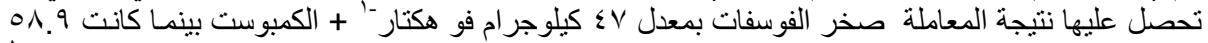

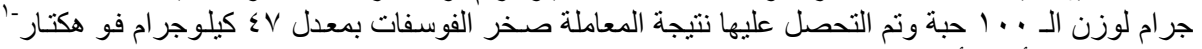

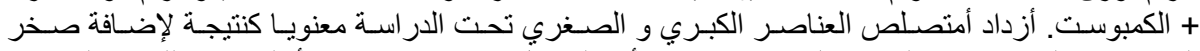

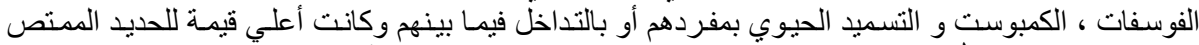

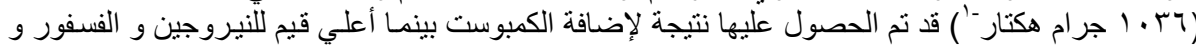

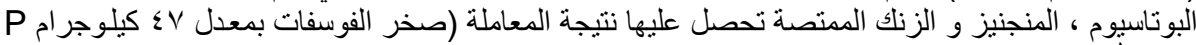

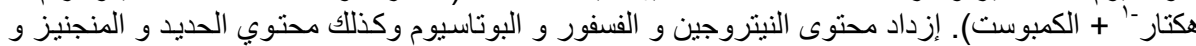

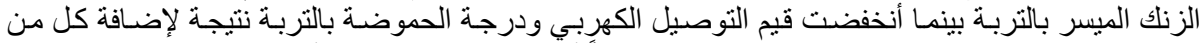

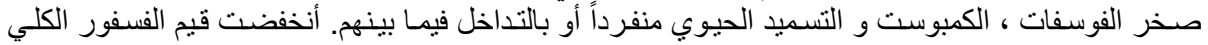

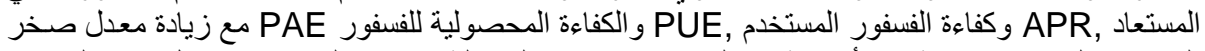

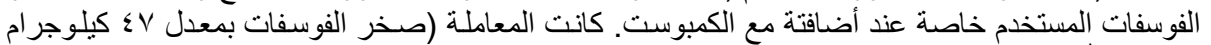

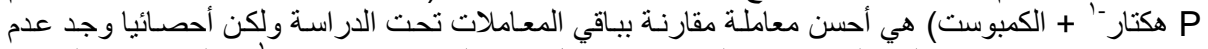

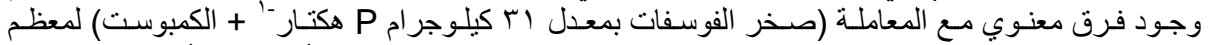

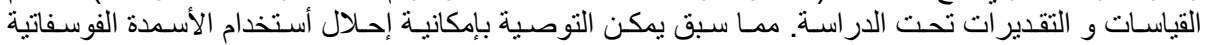

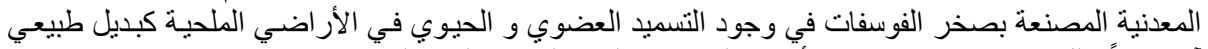
آمن بيئياً يقلل من مخاطر استخدام الأسمدة المعدنية وتلوث الفئ التربة و البيئة المحيطة.

كلية الزراعة - جامعة المنصورة كلية الزراعة بمشتهر - جامعة بنها

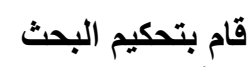

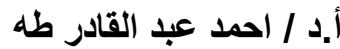

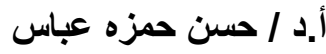

